\title{
PRZYCZYNEK DO DYSKUSJI NAD SKUTKAMI WDROŻENIA ZASADY RÓWNEGO TRAKTOWANIA MĘŻCZYZN I KOBIET W ZAKRESIE DOSTĘPU DO USŁUG UBEZPIECZENIOWYCH ${ }^{1}$
}

Wanda Sułkowska prof. dr hab., Katedra Zarządzania Ryzykiem i Ubezpieczeń, UEK w Krakowie

\section{Wprowadzenie}

Przewidywane przez analityków rynku ubezpieczeń konsekwencje implementacji do prawa krajowego Dyrektywy Rady 2004/113/WE wprowadzającej w życie zasadę równego traktowania mężczyzn i kobiet w zakresie dostępu do towarów i usług skutkować miały istotnym wzrostem składek i świadczeń ubezpieczeniowych w tych obszarach polskiego rynku ubezpieczeń gdzie dotąd płeć stanowiła istotny czynnik oceny ryzyka. Tymczasem $\mathrm{z}$ danych corocznie publikowanych w Raportach KNF trudno znaleźć potwierdzenie tych obaw.

\section{Kwestia równego traktowania w prawie UE ze względu na płeć}

Dyrektywa Rady 2004/113/WE z dnia 13.12.2014 roku wprowadzająca $\mathrm{w}$ życie zasadę równego traktowania kobiet i mężczyzn w zakresie dostępu do towarów i usług oraz dostarczania towarów i usług

1 Zrealizowano ze środków przyznanych na BS nr 025/WF-KZRU/01/2016/6025. 
[Dz.Urz. UE L 2004.373.37] ma na celu rozszerzenie zasady równego traktowania poza sferę rynku pracy i życia zawodowego na inne dziedziny życia codziennego. Dyrektywa ta weszła w życie w dniu 21 grudnia 2004 r., a jej przepisy powinny były zostać wprowadzone do prawa krajów UE najpóźniej z dniem 21 grudnia 2007 r. Należy podkreślić, że Dyrektywa ustanowiła jedynie minimalne wymagania, aby umożliwić krajom UE utrzymanie lub wprowadzenie wyższego albo bardziej rozległego poziomu ochrony.

W odniesieniu do ubezpieczeń $\mathrm{w}$ art. 5 ust. 1 Dyrektywy przyjęto zapis, że ...we wszystkich nowych umowach zawartych najpóźniej po 21 grudnia 2007 r. użycie płci jako czynnika w kalkulowaniu składek $i$ świadczeń do celów ubezpieczenia $i$ związanych ustug finansowych nie powoduje różnic w składkach i odszkodowaniach poszczególnych osób. Jednak w ust. 2 powyższego artykułu stwierdzono, że kraje UE mogą nie stosować tego zakazu w przypadkach, w których użycie płci jest czynnikiem decydującym w ocenie ryzyka opartego na odpowiednich i dokładnych danych aktuarialnych i statystycznych. Korzystając $\mathrm{z}$ tego przepisu kraje UE w aktach prawa implementujących Dyrektywę nie wprowadziły wymogu eliminacji czynnika płci w kalkulacjach składek i świadczeń ubezpieczeniowych, tym samym dopuszczając $\mathrm{w}$ tym zakresie możliwość stosowania nadal wcześniejszych zasad. Jednakże sytuacja uległa istotnej zmianie po tzw. wyroku Test-Achats, gdy 1 marca 2011 roku Trybunał Sprawiedliwości Unii Europejskiej (ETS) wydał wyrok w sprawie C-236/09. Sprawa, którą rozstrzygał ETS dotyczyła stwierdzenia nieważności ustawy, która przenosiła do belgijskiego systemu prawnego uregulowania Dyrektywy Rady 2004/113/WE [www1].

W powyższym wyroku Trybunał zakwestionował zgodność art. 5 ust. 2 Dyrektywy Rady 2004/113/WE z ustanowioną w prawodawstwie wspólnotowym zasadą równego traktowania kobiet i mężczyzn. W konsekwencji przeprowadzonej analizy Trybunał powołał się na regulacje art. 6 Traktatu o Unii Europejskiej, zgodnie z którym Unia uznaje prawa, wolności i zasady określone w Karcie Praw Podstawowych Unii Europejskiej z 7 grudnia 2000 r. [Dz.U. L 373 z 21.12.2004], w której zakazano (art. 21 i 23) dyskryminacji opartej na płci i polecono dążenie do zapewnienia równości mężczyzn i kobiet we wszystkich dziedzinach. Trybunał uznał art. 5 ust. 2 Dyrektywy za nieważny ze skutkiem od dnia 21 grudnia 2012 r., w orzeczeniu w sprawie Test-Achats (C-236/09) i stwierdził nieważność zapisu o możliwości odstępstwa od zasady równego traktowania, który pozwalał ubezpieczycielom na rożne traktowanie mężczyzn i kobiet w odniesieniu do składek i świadczeń ubezpieczeniowych, ze skutkiem od dnia 21 grudnia 2012 r. 
ETS uznał więc, że stosowanie różnych kryteriów przy obliczaniu składki ubezpieczeniowej w odniesieniu do kobiet i mężczyzn, tylko $\mathrm{w}$ aspekcie różnicy płci, jest dyskryminacją i stoi w sprzeczności z równym traktowaniem płci. Niezależnie od sprzecznych poglądów wyrok jest faktem, a zakaz stosowania rozróżnień w tym zakresie powinien być przestrzegany przez ubezpieczycieli [Krukowska, Dyskryminacja...].

W rezultacie unieważnienia przepisu art. 5 ust. 2 Dyrektywy Rady 2004/113/WE, wszystkie państwa członkowskie UE miały obowiązek zmiany regulacji krajowych przyjętych na podstawie tego przepisu. $\mathrm{W}$ dokumencie Komisji Europejskiej nr 2012/C11/01 z dnia 13 stycznia 2012 roku Wytyczne dotyczace stosowania dyrektywy rady 2004/113/we $w$ odniesieniu do ubezpieczeń, w świetle wyroku Trybunału Sprawiedliwości Unii Europejskiej w sprawie c-236/09 (Test-Achats) [Dz.Urz. UE C Nr 11: 1] została wprowadzona generalna zasada, zgodnie z którą począwszy od dnia 21 grudnia 2012 r. zasada równości płci przewidziana w art. 5 ust. 1 Dyrektywy musi być stosowana bez żadnych wyjątków do obliczania składek i świadczeń poszczególnych osób w nowych umowach.

Bezwzględne stosowanie zasady niedyskryminowania ze względu na płeć dotyczy więc kalkulowania składek i świadczeń, jednak w innych obszarach szeroko pojętej działalności ubezpieczeniowej i działaniach z nią związanych czynnik płci może być nadal wykorzystywany w zakresie wynikającym z przepisów Wytycznych Komisji UE. W pkt. 14 Wytycznych ... stwierdzono, że ogólne użycie płci jako czynnika oceny ryzyka jest dozwolone na poziomie zagregowanym, pod warunkiem, że nie wywołuje różnic na poziomie ubezpieczonych. Między innymi, zgodnie z tym artykułem, nadal można pozyskiwać, przechowywać informacje związane z płcią czy też użyć czynnik płci do określonych celów. Ubezpieczyciele sa nadal uprawnieni do wykorzystywania takich danych $w$ celu ustalenia wysokości rezerw techniczno-ubezpieczeniowych zgodnie z przepisami dotyczacymi wypłacalności oraz do monitorowania produktów ubezpieczeniowych z perspektywy wyceny ogólnej [Więcko-Tułowiecka 2012]. Komisja Europejska dopuszcza także stosowanie czynnika płci w umowach reasekuracyjnych, w tym w ustalaniu składek z tytułu takich umów. Użycie kryterium płci do wyceny tych produktów nadal jest możliwe, jeśli nie prowadzi do różnicowania poszczególnych ubezpieczonych ze względu na płeć [Wytyczne dotyczace stosowania..., art. 14]. 


\section{Ochrona przed dyskryminacją w Konstytucji RP oraz implementacja do prawa krajowego Dyrektyw Wspólnot Europejskich (z tego zakresu) obejmujących te zagadnienia}

Konstytucja Rzeczypospolitej Polskiej z dnia 2 kwietnia 1997 r. w art. 32 ust. 1 i 2 stanowi, że Wszyscy sa wobec prawa równi. Wszyscy maja prawo do równego traktowania przez władze publiczne. Nikt nie może być dyskryminowany w życiu politycznym, społecznym lub gospodarczym z jakiejkolwiek przyczyny. Ponadto ustawodawca odniósł się bezpośrednio do kwestii równouprawnienia płci, stanowiąc w art. 33 ust. 1 i 2 Konstytucji, że Kobieta i mężczyzna w Rzeczypospolitej Polskiej maja równe prawa $w \dot{z} y c i u$ rodzinnym, politycznym, społecznym i gospodarczym.

Powyższe normy konstytucyjne zostały uszczegółowione i wzmocnione przepisami Ustawy z dnia 3 grudnia 2010 r. o wdrożeniu niektórych przepisów Unii Europejskiej w zakresie równego traktowania [Dz.U.2010, nr 254 poz. 1700]². W ten sposób zostało wdrożonych w Polsce 5 dyrektyw Wspólnot Europejskich ${ }^{3}$. Ustawa powyższa, w formie katalogu zamkniętego, określa obszary i sposoby przeciwdziałania naruszeniom zasady równego traktowania ze względu na płeć, rasę, pochodzenie etniczne, narodowość, religię, wyznanie, światopogląd, niepełnosprawność, wiek

2 Ustawa weszła w życie z dniem 1 stycznia 2011 roku; zwana jest potocznie ustawą równościową.

3 Są to dyrektywy: 1) Dyrektywa Rady 86/613/EWG z dnia 11 grudnia 1986 r. w sprawie stosowania zasady równego traktowania kobiet i mężczyzn pracujących na własny rachunek, w tym w rolnictwie, oraz w sprawie ochrony kobiet pracujących na własny rachunek w okresie ciąży i macierzyństwa (Dz.Urz. WE L 359 z 19.12.1986: 56; Dz.Urz. UE polskie wydanie specjalne, rozdz. 5, t. 1: 330); 2) Dyrektywa Rady 2000/43/WE z dnia 29 czerwca 2000 r. wprowadzająca w życie zasadę równego traktowania osób bez względu na pochodzenie rasowe lub etniczne (Dz.Urz. WE L 180 z 19.07.2000: 22; Dz.Urz. UE polskie wydanie specjalne, rozdz. 20, t. 1: 23); 3) Dyrektywa Rady 2000/78/WE z dnia 27 listopada 2000 r. ustanawiająca ogólne warunki ramowe równego traktowania w zakresie zatrudnienia i pracy (Dz.Urz. WE L 303 z 02.12.2000: 16; Dz.Urz. UE polskie wydanie specjalne, rozdz. 5, t. 4: 79); 4) Dyrektywa Rady 2004/113/WE z dnia 13 grudnia 2004 r. wprowadzająca w życie zasadę równego traktowania mężczyzn i kobiet w zakresie dostępu do towarów i usług oraz dostarczania towarów i usług (Dz.Urz. UE L 373 z 21.12.2004: 37); 5) Dyrektywa 2006/54/WE Parlamentu Europejskiego i Rady z dnia 5 lipca 2006 r. w sprawie wprowadzenia w życie zasady równości szans oraz równego traktowania kobiet i mężczyzn w dziedzinie zatrudnienia i pracy (wersja przeredagowana) (Dz.Urz. UE L 204 z 26.07.2006: 23). 
lub orientację seksualną. Instytucjami, którym w art. 18 omawianej ustawy powierzono zadania dotyczące realizacji zasady równego traktowania są Rzecznik Praw Obywatelskich ${ }^{4}$, Pełnomocnik Rządu do spraw Równego Traktowania [Rozporządzenie Rady Ministrów z dnia 22 kwietnia 2008 r...] oraz Pełnomocnik Rządu do spraw Społeczeństwa Obywatelskiego ${ }^{5}$. Drugim podstawowym aktem prawnym implementującym dyrektywy antydyskryminacyjne do polskiego porządku prawnego jest Kodeks pracy (Kp) [Ustawa $\mathrm{z}$ dnia 26 czerwca 1974 r...]. Dostosowywanie polskiego Kodeksu pracy do wymogów prawa unijnego realizowane było w ramach kilku nowelizacji Kp.

\section{Problem równego traktowania w ustawie o działalności ubezpieczeniowej i reasekuracyjnej}

Art. 5 ust. 1 dyrektywy zakazujący różnicowania składek i świadczeń ubezpieczeniowych ze względu na płeć nie został wprowadzony do polskiego prawa ubezpieczeniowego w postulowanym brzmieniu. Natomiast polski ustawodawca, w roku 2009 w ustawie o działalności ubezpieczeniowej ${ }^{6}$ wprowadził dodatkowy art. 18a, określający warunki dopuszczające stosowanie kryterium płci w ocenie ryzyka i różnicowania składek i świadczeń.

Wobec decyzji podjętych przez Trybunał Sprawiedliwości Unii Europejskiej w dniu 1 marca 2011 r. w sprawie Test-Achats od 21 grudnia 2012 r. obowiązują przepisy, które nie pozwalają na różnicowanie składki ubez-

$4 \quad$ W Polsce urząd Rzecznika Praw Obywatelskich rozpoczął działalność w 1988 r. Ustawa o Rzeczniku Praw Obywatelskich została uchwalona 15 lipca 1987 r. (Dz.U. nr 21, poz. 123 - tekst jednolity uwzględniający zmiany dokonane w niej po zmianie ustroju, w tym po uchwaleniu nowej Konstytucji - Dz.U. 2001, nr 14, poz. 147). Instytucja RPO jest umocowana w Konstytucji z 1997 r. (art. 80 oraz 208-212), w odrębnym podrozdziale IX rozdziału - Organy Kontroli Państwowej i Ochrony Prawa.

5 Od 8 stycznia 2016 Urząd Pełnomocnika Rządu do spraw Społeczeństwa Obywatelskiego i Pełnomocnika Rządu do spraw Równego Traktowania pełni jedna osoba; [www2].

6 Ustawa z dnia 13 lutego 2009 r. o zmianie ustawy o działalności ubezpieczeniowej oraz niektórych innych ustaw, Dz.U. 2009, nr 42, poz. 341, która weszła w życie 18.06.2009 r. 
pieczeniowej ze względu na płeć. Tak więc i w prawie krajowym konieczne było wprowadzenie stosownych zmian. Ustawą z dnia 14.12.2012 r. o zmianie ustawy o działalności ubezpieczeniowej [Dz.U. 2013, poz. 53] nadano art. 18a nowe brzmienie: Zastosowanie przez zakład ubezpieczeń kryterium płci w kalkulowaniu składek ubezpieczeniowych $i$ świadczeń nie może prowadzić do różnicowania składek ubezpieczeniowych i świadczeń poszczególnych osób. Przepis dostosowujący polskie prawo do decyzji podjętych przez ETS został wprowadzony ustawą z dnia 14 grudnia 2012 roku i ogłoszony 14 stycznia 2013 roku, a formalnie wszedł w życie 28 stycznia 2013 r. W tej sytuacji zakłady ubezpieczeń w okresie od 21 grudnia 2012 r. do 27 stycznia 2013 r. nie miały prawnego obowiązku zmiany dotychczasowych zasad obliczania składek i świadczeń, a zatem były uprawnione do stosowania kryterium płci.

Obowiązująca od 1 stycznia 2016 r. ustawa z dnia 11 września 2015 r. o działalności ubezpieczeniowej i reasekuracyjnej [Dz.U. z dnia 10 listopada 2015 r., poz. 1844], której wprowadzenie wynikało z konieczności implementowania do krajowego porządku prawnego przepisów Dyrektywy 2009/138/WE Parlamentu Europejskiego i Rady z dnia 25 listopada 2009 r. w sprawie podejmowania i prowadzenia działalności ubezpieczeniowej i reasekuracyjnej - Wypłacalność II (ang. Solvency II) [Dz.Urz. UE L 335 z 17.12.2009: 1] zawiera również regulacje przyjęte $\mathrm{w}$ art. 18a w nowelizacji z dnia 14 grudnia 2012 roku oraz w art. 18 b wprowadzone w ramach nowelizacji w roku 2009, które są zapisane w obecnej ustawie w art. 34 ust. 1 i 2.

\section{Rynkowe konsekwencje zmian ustawowych w zakresie równego traktowania}

W zgodnym przekonaniu uczestników rynku ubezpieczeniowego konsekwencją zrównania płci w dziedzinie ubezpieczeń powinien być wzrost składek dla tych osób, które charakteryzowały się mniejszym ryzykiem, a więc w ubezpieczeniu na życie ( $\mathrm{z}$ wyjątkiem ubezpieczeń rentowych [Stroiński 2014: 26]) kobiet, gdyż ich niższe ryzyko śmierci, związane z płcią, nie może już być brane pod uwagę przy określaniu składki ubezpieczeniowej.

Wobec niemożności uwzględnienia czynnika płci w ocenie ryzyka przewidywano, że zmienione zasady spowodują istotne konsekwencje zarówno dla ubezpieczonych jak i dla ubezpieczycieli. W przypadku 
ubezpieczających zmiany miały dotyczyć wysokości składki i świadczeń. Konsekwencje w działaniach ubezpieczycieli wynikają z nowego spojrzenia na ryzyko i sposobów oceny tegoż ryzyka. W przypadku bowiem, gdy nie uwzględnia się płci traktowanej wcześniej jako jeden z podstawowych czynników ryzyka, to trzeba zmienić wagę w tzw. underwritingu, innych czynników ryzyka, uwzględnianych przez zakłady ubezpieczeń.

Równocześnie przewidywano, że nastąpi spadek składek dla osób, które charakteryzują się wyższym ryzykiem, a więc mężczyzn [Stroiński 2014: 27 i nast.], tak w ubezpieczeniach na życie, tzn. w grupie 1 Działu I, jak i w grupie 3 tego działu, obejmującej Ubezpieczenia na życie, jeżeli sa związane $z$ ubezpieczeniowym funduszem kapitałowym, a także ubezpieczenia na życie, w których świadczenie zakładu ubezpieczeń jest ustalane w oparciu o określone indeksy lub inne wartości bazowe [Załącznik do ustawy z dnia 11 września 2015 r...].

Ten pogląd znajdował również potwierdzenie w opublikowanych w Dzienniku Urzędowym Unii Europejskiej, (13.1.2012.) wytycznych dotyczacych stosowania Dyrektywy Rady 2004/113/WE w odniesieniu do ubezpieczeń wświetle wyroku Trybunału Sprawiedliwości Unii Europejskiej w sprawie C-236/09, gdzie płeć zgłaszana jest jako istotny dotąd czynnik $\mathrm{w}$ ocenie ryzyka. $\mathrm{Z}$ ocen zawartych $\mathrm{w}$ tabeli 1 sporządzonej $\mathrm{w}$ oparciu o dane zawarte w załączniku 3 do Wytycznych dotyczacych stosowania dyrektywy rady 2004/113/we w odniesieniu do ubezpieczeń, $w$ świetle wyroku Trybunału Sprawiedliwości Unii Europejskiej w sprawie C-236/09 (Test-Achats). wynika, że w przypadku połowy poddanych ocenie rodzajów ubezpieczeń $50 \%$ lub więcej wszystkich badanych stowarzyszeń branżowych, stowarzyszeń aktuarialnych, właściwych władz i organów do spraw równości uważa, że płeć jest często uwzględniana w ocenie ryzyka, a w przypadku 4 z pozostałych sześciu ubezpieczeń, w opinii 10 do $50 \%$ wszystkich badanych, używana jest czasem. Opinia, że płeć stosowana jest często jako czynnik ryzyka, dotyczy prywatnych ubezpieczeń, ubezpieczeń na wypadek poważnej choroby, ubezpieczeń na wypadek niepełnosprawności/utraty dochodu, ubezpieczeń na życie, produktów rentowych oraz ubezpieczeń pojazdów.

Jak już wyżej powiedziano, w odniesieniu do wszystkich oferowanych obecnie na polskim rynku ubezpieczeniowym produktów w analizie ryzyka winien być respektowany wyrok ETS, a konsekwencją są zmiany w sposobie wyliczania składek ubezpieczeniowych nie tylko $w$ ubezpieczeniach na życie (Dz. I, gr. 1) oraz $w$ ubezpieczenia na życie, jeżeli sa zwiazane $z$ ubezpieczeniowym funduszem kapitałowym..., (Dz. I, gr. 3) lecz również w ubezpieczeniach komunikacyjnych, (Dz. II, gr. $3.1 \mathrm{oraz}$ gr. 10), w których to grupach produktowych czynnik płci wcześniej był powszechnie szeroko stosowany. 


\begin{tabular}{|l|c|c|c|}
\hline \multirow{2}{*}{ Kategoria produktu } & \multicolumn{3}{c|}{ Czynniki } \\
\cline { 2 - 4 } & płeć & wiek & niepełnosprawność \\
\hline Prywatne ubezpieczenia & ++ & ++ & + \\
\hline $\begin{array}{l}\text { Ubezpieczenie na wypadek poważnej cho- } \\
\text { roby }\end{array}$ & ++ & ++ & + \\
\hline $\begin{array}{l}\text { Ubezpieczenie na wypadek niepełnospraw- } \\
\text { ności/utraty dochodu }\end{array}$ & ++ & ++ & ++ \\
\hline Ubezpieczenie na życie & ++ & ++ & ++ \\
\hline Produkty rentowe & ++ & ++ & + \\
\hline Ubezpieczenie pojazdu & ++ & ++ & + \\
\hline Ubezpieczenie podróżne & + & ++ & + \\
\hline Ubezpieczenie od wypadku & + & + & + \\
\hline Ubezpieczenie opieki długotrwałej & + & + & + \\
\hline Ubezpieczenie kredytu/ochrona spłat & + & + & + \\
\hline Ubezpieczenie domu & 0 & + & 0 \\
\hline Ubezpieczenie odpowiedzialności cywilnej & 0 & + & 0 \\
\hline
\end{tabular}

++ zgłaszany jako często używany (przez $50 \%$ lub więcej wszystkich badanych stowarzyszeń branżowych, stowarzyszeń aktuarialnych, właściwych władz i organów do spraw równości)

+ zgłaszany jako czasem używany (przez 10 do 50\% wszystkich badanych stowarzyszeń branżowych, stowarzyszeń aktuarialnych, właściwych władz i organów do spraw równości)

o zgłaszany jako rzadko używany (przez mniej niż 10\% wszystkich badanych stowarzyszeń branżowych, stowarzyszeń aktuarialnych, właściwych władz i organów do spraw równości).

W przypadku gdy częstotliwość zgłoszonego użycia doprowadziła do różnic między trzema grupami, na których oparto ocenę (tj.: stowarzyszeń branżowych/stowarzyszeń aktuarialnych/właściwych władz i organów do spraw równości); ocena w tabeli przedstawia wyniki z dwóch grup w tej samej kategorii. Kategorie produktu mogą obejmować szeroką gamę różnych typów produktów oferowanych na rynku. W tabeli nie uwzględniono produktów wiązanych np. połączenia rachunku bieżącego z produktem ubezpieczeniowym.

Tabela 1. Zgłoszone użycie czynników do oceny ryzyka wg produktu (na podstawie częstotliwości zgłoszonego użycia przez zainteresowane podmioty)

Źródło: opracowanie własne na podstawie: Wytyczne dotyczące stosowania dyrektywy rady 2004/113/we w odniesieniu do ubezpieczeń, w świetle wyroku Trybunału Sprawiedliwości Unii Europejskiej w sprawie C-236/09 (Test-Achats) (nr 2012/c11/01) z dnia 13 stycznia 2012 r. (Dz.Urz. UE C Nr 11: 1).

Ocena a posteriori na ile powyższe przewidywania znalazły odzwierciedlenie w wynikach rynku ubezpieczeniowego możliwa jest zatem wyłącznie w oparciu o dane ogólnodostępne, których zmiany w czasie odzwierciedlają jednak wpływ wszystkich istotnych czynników je determinujących, a nie tylko związanych $\mathrm{z}$ analizowaną problematyką, a rozdzielenie wywołanych przez nie efektów jest niemożliwe. Pozostaje zatem jedynie możliwość pośredniego wnioskowania $\mathrm{z}$ danych ogólnych przedstawionych na rysunkach 1-3, dotyczących trzech wybranych 
grup ubezpieczeń, jak można przyjąć, najbardziej narażonych na konsekwencje braku możliwości różnicowania ryzyka ze względu na płeć, tj. ubezpieczeń na życie oraz ubezpieczeń komunikacyjnych: AC - grupa 3 Działu II i OC - grupa 10 Działu II, z uwzględnieniem wyłącznie umów indywidualnych.

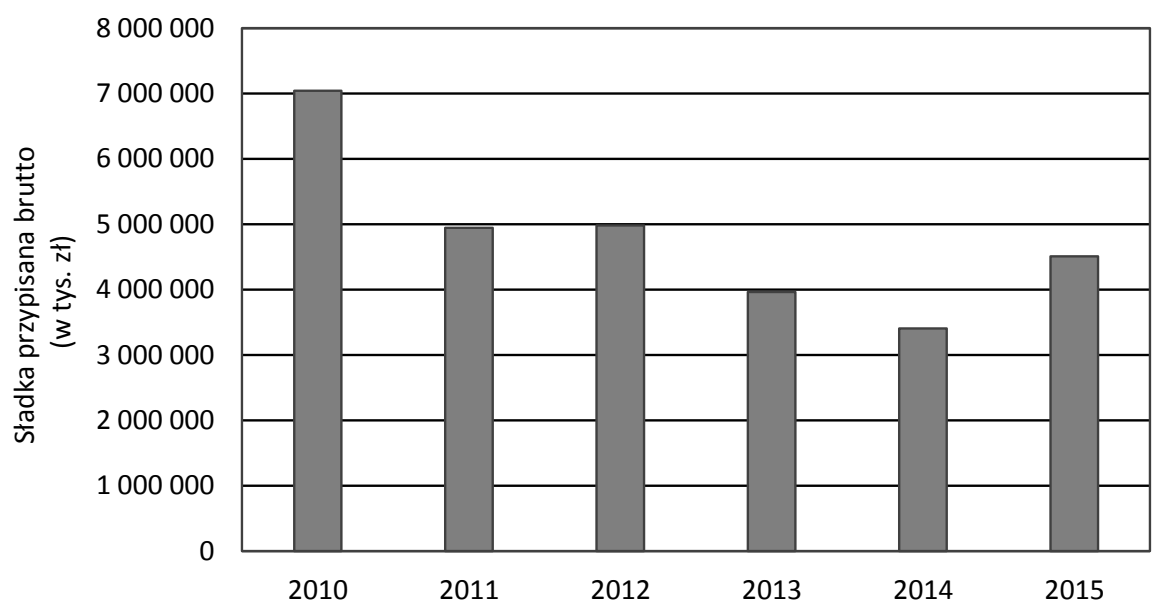

Rysunek 1. Składka przypisana brutto z tytułu umów indywidualnych w Dz. I, grupie 1, w latach 2010-2015

Źródło: opracowanie własne na podstawie danych za lata 2010-2013 wg Sprawozdań statystycznych KNF, dane za lata 2014 i 2015 wg Raportu GUS Polski rynek ubezpieczeniowy 2015 http://www.beinsured.pl/analizy-i-raporty/gus-spadek-wynikow-finansowych-na-polskimrynku-ubezpieczen-w-2015-r-,248.html (dostęp: 15.01.2017).

We wszystkich analizowanych przypadkach zmiany składki przypisanej brutto $\mathrm{z}$ umów indywidualnych nie potwierdzają przewidywań, że konsekwencją zrównania ryzyka płci w dziedzinie ubezpieczeń będzie wzrost składek ogólem. Wręcz odwrotnie, w dwóch kolejnych latach po wejściu w życie zakazu różnicowania składek ubezpieczeniowych i świadczeń poszczególnych osób wg kryterium płci, tj. w roku 2013 i 2014 w każdej z ww. grup ubezpieczeń nastąpiło znaczące obniżenie składki przypisanej brutto.

W przypadku ubezpieczeń na życie, grupa 1 Dział I, wg opinii ekspertów głównymi przyczynami obniżenia sumy składek przypisanych brutto w latach 2013 i 2014 była zmiana preferencji nowych klientów na rzecz ubezpieczeń nażycie związanych z funduszem kapitałowym i zwiększony popyt na produkty strukturyzowane - grupa 3 Działu I, a także spadek liczby aktywnych i nowych umów o charakterze polisolokat. Czy i w jakim 
stopniu trent spadkowy składki przypisanej brutto z ubezpieczeń na życie związany z powyższymi czynnikami został wówczas osłabiony ewentualnym wzrostem składki w związku z nowym podejściem do oceny ryzyka trudno ocenić z braku bardziej szczegółowych danych. Warto zaznaczyć, że dostępne dane publikowane przez KNF i GUS utrudniają szczegółową analizę rynku i uchwycenie różnic w wysokości składki przypisanej brutto $\mathrm{z}$ tytułu umów indywidualnych, a tym bardziej uwzględnienie różnic w składkach z umów zawieranych przez mężczyzn i kobiety

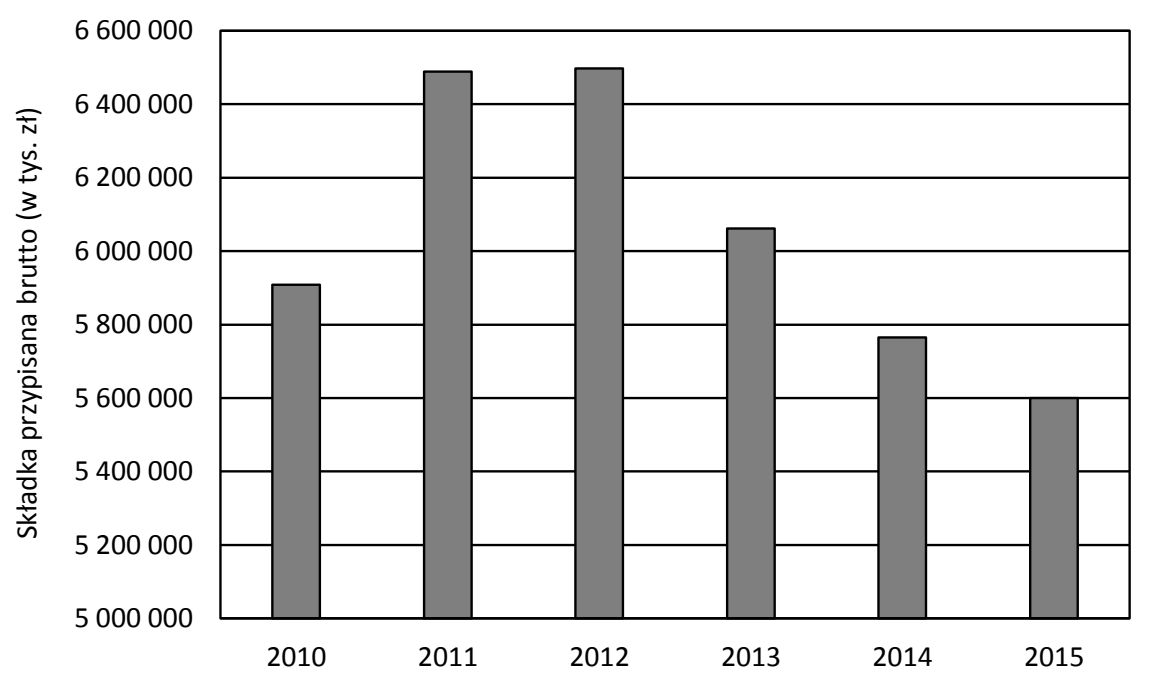

Rysunek 2. Składka przypisana brutto z tytułu umów indywidualnych w ramach ubezpieczenia OC wynikającego z posiadania pojazdów mechanicznych w latach 2010-2015

Źródło: opracowanie własne na podstawie danych za lata 2010-2013 wg Sprawozdań statystycznych KNF, dane za lata 2014 i 2015 wg Raportu GUS Polski rynek ubezpieczeniowy 2015, http://www.beinsured.pl/analizy-i-raporty/gus-spadek-wynikow-finansowych-na-polskimrynku-ubezpieczen-w-2015-r-,248.html (dostęp: 15.01.2017).

7 W Sprawozdaniach statystycznych KNF za lata 2014 i 2015 dotyczących ubezpieczeń Działu I brak danych w rozbiciu na grupy 1-4 (dostępne są jedynie dane dla ubezpieczeń dodatkowych - grupy 5), natomiast w Raporcie GUS Polski rynek ubezpieczeniowy 2015 w danych za lata 2014 i 2015 nie wyodrębniono liczby umów osób fizycznych, natomiast w ramach składki przypisanej brutto wyodrębniono, inaczej niż w latach poprzednich w KNF, składkę sektora gospodarstw domowych, tzw. pozostałych (inne, to sektor gospodarstw domowych: pracodawcy i osoby pracujące na własny rachunek). 


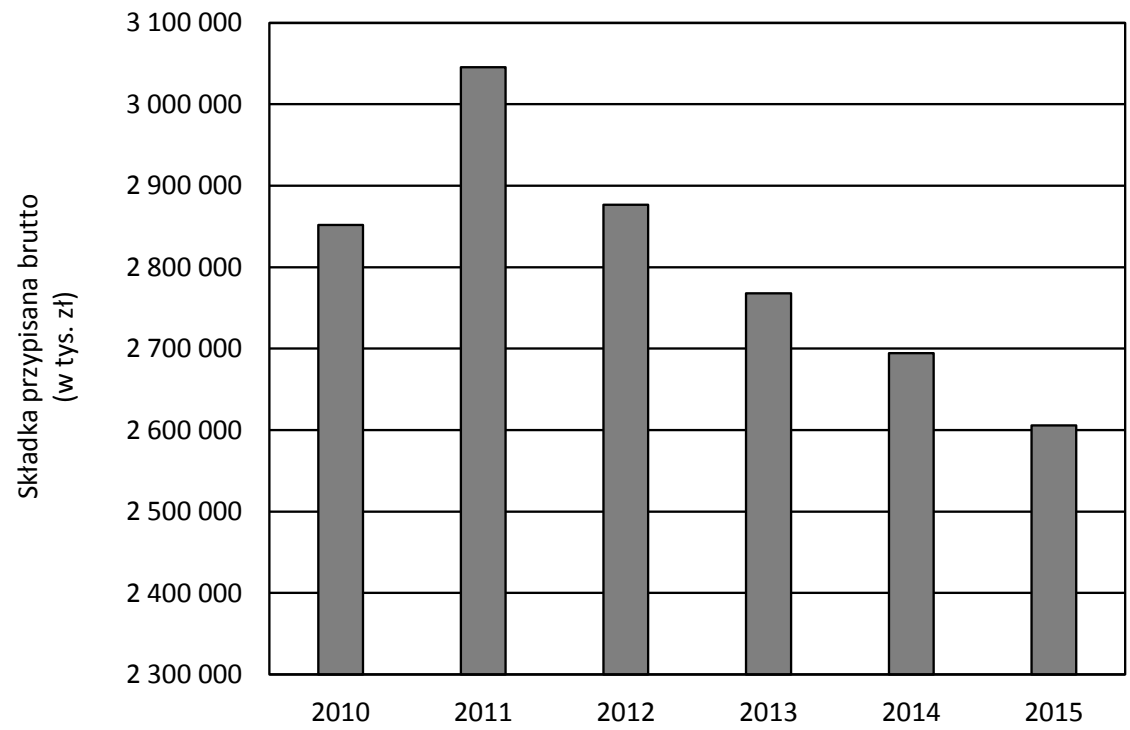

Rysunek 3. Składka przypisana brutto z umów indywidualnych w ramach ubezpieczenia casco pojazdów lądowych osób fizycznych w latach 2010-2015 Źródło: opracowanie własne na podstawie danych za lata 2010-2013 wg Sprawozdań statystycznych KNF, dane za lata 2014 i 2015 wg Raportu GUS Polski rynek ubezpieczeniowy 2015, http://www.beinsured.pl/analizy-i-raporty/gus-spadek-wynikow-finansowych-na-polskimrynku-ubezpieczen-w-2015-r-,248.html (dostęp: 15.01.2017).

W przypadku ubezpieczeń komunikacyjnych brak jednoznacznych przesłanek dla wyjaśnienia zdecydowanie niższych wartości sumy składek z indywidualnych umów ubezpieczeń AC - grupa 3 Działu II o OC. Można tu wymienić najczęściej eksponowane przyczyny takiego stanu rzeczy, tj. spadek popytu na samochody nowe i z rynku wtórnego lecz o wyższym standardzie i tym samym droższe oraz walkę konkurencyjną na rynku ubezpieczeń komunikacyjnych, $\mathrm{w}$ tym stosowanie cen dumpingowych. $\mathrm{Z}$ dostępnych danych wynika przy tym, że w analizowanym okresie 2014-2015, przeciętna wartość składek z polis indywidualnych w obu rodzajach ubezpieczeń nie wzrosła, lecz odwrotnie zmalała. Według danych z Raportu Polskiej Izby Ubezpieczeń ${ }^{8}$ wartość składki z umów osób fizycznych przypadającej na jedną polisę w grupie 3 (AC) wynosiła 773 zł w 2013 r., w porównaniu z 797 zł w roku 2012, czyli o 3\% mniej, a wartość średniej składki z umowy osób fizycznych w grupie 10

8 Rynek ubezpieczeń komunikacyjnych w Polsce Przegląd danych z lat 2011-2013, PIU, Warszawa, lipiec 2014. Raport jest bardzo obszerną analizą polskiego runku ubezpieczeń komunikacyjnych na szerokim tle innych krajów UE. 
(OC) wynosiła 355 zł w 2013 r., w porównaniu z 378 zł w roku 2012, czyli o 6,2\% mniej. Spadek przeciętnej składki w grupie umów z osobami fizycznymi, wbrew oczekiwaniom, wzmocnił jeszcze trend spadkowy w zakresie składki ogółem w ubezpieczeniach komunikacyjnych.

\section{Podsumowanie}

W licznych publikacjach w okresie nowelizacji ustawy o działalności ubezpieczeniowej... w związku z wyrokiem ETS oraz wytycznymi do dyrektywy równościowej, tj. na przełomie roku 2012/13, sugerowano możliwość istotnego wzrostu składki ogółem z tytułu ww. ubezpieczeń, jako konsekwencji zrównania składki dla kobiet i mężczyzn na średnim poziomie wyższym od dotychczasowego. Oczywiście, założenie takie przyjmowano bez uwzględnienia ewentualnych zmian innych istotnych determinant wysokości składki ogółem oraz przy domyślnym założeniu, że wzrost cen składek, a w szczególności zdecydowanie wyższych składek dla kobiet, nie wpłynie na liczbę osób decydujących się na zawarcie umowy ubezpieczenia na pogorszonych warunkach finansowych. Brak jednak dostępu do szczegółowych danych z zakresu powyższych zagadnień, gdyż dysponują nimi wyłącznie zakłady ubezpieczeń, a kwestie kalkulacji składek i świadczeń oraz struktura ubezpieczonych należą do pilnie strzeżonych.

\section{Bibliografia}

Dyrektywa Rady 2004/113/WE z dnia 13 grudnia 2004 r. wprowadzająca w życie zasadę równego traktowania mężczyzn i kobiet w zakresie dostępu do towarów i usług oraz dostarczania towarów i usług, Dz.Urz. UE L 2004.373.37.

Dyrektywa 2006/54/EC Parlamentu Europejskiego i Rady z dnia 5 lipca 2006 r. w sprawie wprowadzenia w życie zasady równości szans oraz równego traktowania kobiet i mężczyzn w dziedzinie zatrudnienia i pracy, Dz.U. UE L 2006.204.23.

Dyrektywa 2009/138/WE Parlamentu Europejskiego i Rady z dnia 25 listopada 2009 r. w sprawie podejmowania i prowadzenia działalności ubezpieczeniowej i reasekuracyjnej - Wypłacalność II, Dz.Urz. UE L 335 z 17.12.2009.

Informacja dla Instytucji Unii Europejskiej - Wytyczne dotyczące stosowania dyrektywy 2004/113/EC do umów ubezpieczenia w świetle wyroku Europejskiego Trybunału Sprawiedliwości w sprawie C-236/09 (Test-Achats), Dz.U. UE C 2012.11.1.3. 
Karta Praw Podstawowych Unii Europejskiej z 7 grudnia 2000 r.; Dz.U. L 373 z 21.12.2004. Kodeks pracy - Ustawa z dnia 26 czerwca 1974 r., Dz.U. 1974, nr 24, poz. 141 z późn. zm. Konstytucja Rzeczypospolitej Polskiej z dnia 2 kwietnia 1997 r., Dz.U. 1997, nr 78, poz. 483. Krukowska S., Dyskryminacja w kalkulacji składek ubezpieczeniowych, http://www.na -zycie.ubezpieczenie.com.pl/dyskryminacja_w_kalkulacji_skladek_ubezpieczeniowych/50,11473,0.html.

Raport GUS Polski rynek ubezpieczeniowy 2015; http://www.beinsured.pl/analizy-iraporty/gus-spadek-wynikow-finansowych-na-polskim-rynku-ubezpieczen-w2015-r-,248.html.

Rozporządzenie Rady Ministrów z dnia 22 kwietnia 2008 r. w sprawie Pełnomocnika Rządu do spraw Równego Traktowania; Dz.U., nr 75, poz. 450.

Rynek ubezpieczeń komunikacyjnych w Polsce Przegląd danych z lat 2011-2013, PIU, Warszawa, lipiec 2014.

Stroiński E. (2014), Gender jako czynnik ryzyka w ubezpieczeniu na życie, Akademia Finansów i Biznesu Vistula, Warszawa, 2(40).

Ustawa z dnia 11 września 2015 r. o działalności ubezpieczeniowej i reasekuracyjne, Dz.U. z dnia 10 listopada 2015 r., poz. 1844.

Ustawa z dnia 14 grudnia 2012 r. o zmianie ustawy o działalności ubezpieczeniowej, Dz.U. 2013, poz. 53.

Ustawa z dnia 15 lipca 1987 r. o Rzeczniku Praw Obywatelskich, Dz.U., nr 21, poz. 123 - tekst jednolity uwzględniający zmiany dokonane w niej po zmianie ustroju, w tym po uchwaleniu nowej Konstytucji - Dz.U. 2001, nr 14, poz. 147.

Ustawa z dnia 22 maja 2003 r. o działalności ubezpieczeniowej, Dz.U., nr 124, poz. 1151 z późn. zm.

Ustawa z dnia 3 grudnia 2010 r. o wdrożeniu niektórych przepisów Unii Europejskiej w zakresie równego traktowania, Dz.U. 2010, nr 254, poz. 1700.

Więcko-Tułowiecka M. (2012), Dyskryminacja płciowa w ubezpieczeniach - wytyczne dotyczqce stosowania dyrektywy 2004/113/KE w zakresie ubezpieczeń majątkowych i osobowych w świetle wyroku Europejskiego Trybunału Sprawiedliwości - sprawa C236/09 (Test-Achats), "Monitor Ubezpieczeniowy”, nr 50.

Wyrok Trybunału Sprawiedliwości Unii Europejskiej w sprawie c-236/09 (Test-Achats) (nr 2012/c11/01) z dnia 13 stycznia 2012 r., Dz.Urz. UE C Nr 11.

Wytyczne dotyczące stosowania dyrektywy rady 2004/113/we w odniesieniu do ubezpieczeń, w świetle wyroku Trybunału Sprawiedliwości Unii Europejskiej w sprawie c-236/09 (Test-Achats) (nr 2012/c11/01) z dnia 13 stycznia 2012 r., Dz.Urz. UE C Nr 11.

Załącznik do ustawy z dnia 11 września 2015 r. (poz. 1844), Dz.U. 2015, poz. 1844; Dz.U. 2016, poz. 615.

[www1] http://www.lex.pl/czytaj/-/artykul/ets-na-temat-dyskryminacji-w-ubezpiecze niach (dostęp: 7.01.2017).

[www2] https://bip.kprm.gov.pl/kpr/bip-kancelarii-prezesa/1147,Witamy-na-stronie-Biu letynu-Informacji-Publicznej-Kancelarii-Prezesa-Rady-Minist.html (dostęp: 15.01.2017). 


\section{PRZYCZYNEK DO DYSKUSJI NAD SKUTKAMI WDROŻENIA ZASADY RÓWNEGO TRAKTOWANIA MĘŻCZYZN I KOBIET W ZAKRESIE DOSTĘPU DO UStUG UBEZPIECZENIOWYCH}

Dyrektywa Rady 2004/113/WE wprowadzająca w życie zasadę równego traktowania mężczyzn i kobiet w zakresie dostępu do towarów i usług oraz dostarczania towarów i usług (Akta Dyrektywy 2004/113/UE, Dziennik Urzędowy Unii Europejskiej Dz.U. L 373 z 21.12.2004: 37-43) ma na celu zapewnienie równego traktowania mężczyzn i kobiet w celu rozszerzenia zasady równego traktowania poza sferę rynku pracy i życia zawodowego na inne dziedziny życia codziennego. W dyrektywie przyjęto zapis, że zastosowanie w odniesieniu do usług ubezpieczeniowych Dyrektywy Rady 2004/113/WE zabrania użycia płci jako czynnika występującego w kalkulowaniu składek oraz wyliczaniu wysokości świadczeń ubezpieczeniowych w umowach ubezpieczenia zawartych po 21 grudnia 2007 r.

Konsekwencje implementacji do prawa krajowego Dyrektywy Rady 2004/113/WE wprowadzającej w życie zasadę równego traktowania mężczyzn i kobiet w zakresie dostępu do towarów i usług w odniesieniu do składek i świadczeń ubezpieczeniowych powinny być odczuwalne w wielu obszarach polskiego rynku ubezpieczeń życiowych i majątkowych.

Słowa kluczowe: dyrektywa Rady Unii Europejskiej, równe traktowanie mężczyzn i kobiet, polski rynek ubezpieczeń życiowych i majątkowych.

\section{CONTRIBUTION TO THE DISCUSSION ON THE EFFECTS OF IMPLEMENTATION OF THE PRINCIPLE OF EQUAL TREATMENT BETWEEN MEN AND WOMEN IN THE ACCESS TO INSURANCE SERVICES}

Council Directive 2004/113/EC implementing the principle of equal treatment between men and women in the access to and supply of goods and services (Acts of Directive 2004/113 / EU, Official Journal of the European Union OJ L 373 of 21.12. 2004: 37-43) has been designed to ensure extension of equal treatment outside the spheres of the labor market and work environment to areas of everyday activities. The Directive adopts a provision which applies to insurance services and it prohibits the use of sex as a factor in the calculation of premiums and benefits for the purposes of insurance and related financial services concluded after 21 December 2007.

The consequences of the implementation of the principle of equal treatment between men and women in the access to goods and services in respect of insurance premiums and benefits should be noticeable in many areas of the Polish market of life insurance and property insurance.

Keywords: The council directive of the EU, equal treatment for men and women, the Polish market of life insurance and property insurance. 